Journal of Economics and Behavioral Studies

Vol. 6, No. 5, pp. 411-417, May 2014 (ISSN: 2220-6140)

\title{
Prisoner-warder ratio parity in a South African Correctional Centre: Repercussions on prison work environment and correctional security personnel
}

\author{
Vuyokazi Magungxu, Willice Abuya, *Philani Moyo \\ University of Fort Hare, South Africa \\ *pmoyo@ufh.ac.za
}

\begin{abstract}
South Africa has one of the highest inmate populations in the world. In order for the South African Correctional Services system to provide an environment conducive for the appropriate rehabilitation and reformation of its many inmates, it requires a balanced prisoner-warder ratio based on international standards. But is this the case in South African prisons? This is one of the questions that this article engages as it examines the prisoner-warder ratio at the East London Maximum Correctional Centre (ELMCC) in an effort to understand the effects of prison overcrowding on the prison work environment and correctional personnel. Based on empirical evidence gathered through qualitative techniques, the study finds a disproportionate prisoner-warder ratio at the ELMCC. This disproportion has a number of negative effects on the prison work environment and direct security personnel on duty. For example, high absenteeism is rife with warders frequently on sick leave while others are regularly on temporary incapacity leave. High stress levels are also a major problem pushing many warders into alcohol abuse. Cognitive job satisfaction and organizational commitment are also negatively affected by this disproportion with the majority of warders indicating poor work performance due to low morale and lack of motivation.
\end{abstract}

Keywords: Prisoner, warder, overcrowding, work environment, South Africa

\section{Introduction}

South Africa has the highest inmate population in Africa. The latest figures released by Correctional Services Minister Sibusiso Ndebele show that there are 156370 inmates in South African correctional facilities (Citypress, 2013). This figure includes 112416 sentenced offenders and 43954 remand detainees (Citypress, 2013). These inmate figures are far much higher than those of Nigeria - the continent's most densely populated country with 136 million people - which has 54144 prisoners (World Prison Brief, 2013). It is only Ethiopia with an inmate population of 112361 (World Prison Brief, 2013) which comes somewhat close to South Africa. Globally, South Africa has the world's seventh highest number of prisoners - outranking countries with up to nearly five times its population. This high number of South African inmates is however much lower in comparison to other countries in the Global South. For example, South Africa's economic and political partners in the BRICS group (Brazil, Russia, India and China) have far higher inmate populations. Brazil has 419551 inmates, Russia has 888, 014, India has 358, 368 while China has 1.6 million inmates (IOL News, 2008). Perhaps this high number of inmates in South Africa's BRICS partners is expected given their large populations compared to South Africa's 53.1 million people. This should not however be construed to mean that a large population in any given country has a direct relationship with high inmate numbers.

South Africa's large prisoner population has resulted in prison overcrowding. For example, Johannesburg's Medium a Prison is $202 \%$ overcrowded with 81 men sharing space designed for 40 inmates in one cell (Evans, 2013). Due to this overcrowding, many inmates in some prisons across the country have less than $1.2 \mathrm{~m}^{2}$ personal space - the size of an average office table - in which they sleep, eat and spend 23 hours a day (Department of Correctional Services (DCS), 2009). It is also common to find prisoners sharing bed space, or sleeping on floors and under beds. The hygienic conditions in these crowded prisons are also appalling with many prisons having open communal toilets shared by as many as 65 men as was the case in Johannesburg's Medium A Prison in 2013 (Evans, 2013). Even though the South African government has built a number of prisons since 1994 to accommodate more prisoners and ease congestion in the existing ones, this has not solved the overcrowding problem. Consequently, many inmates remain in inhumane crowded conditions. This situation is made worse by the separation and accommodation of offenders along gender lines and 
according to their types of offences. The effect of this is that while some prisons are under-occupied, others are over-stretched, some with up to $200 \%$ occupancy (DCS, 2008, Evans, 2013). Within the foregoing context, this article examines the prisoner-warder ratio at the East London Maximum Correctional Centre (ELMCC) in an effort to understand the effects of prison overcrowding on the prison work environment and correctional personnel. The article firstly maps overcrowding in South African correctional facilities by examining the ratio imbalance between offenders and those who function as 'agents of rehabilitation', i.e., the prison warders. It moves on to discern the negative effects of this ratio imbalance on offenders and prison personnel mandated with the responsibility of rehabilitating inmates.

\section{Literature Review}

Prisoner-warder ratio parity and overcrowding in South African prisons: The latest statistics show that South Africa's prison population of 156370 equates to a prison population rate (per 100000 of national population) of 294 based on an estimated national population of 53.1 million (World Prison Brief, 2013). This high prison population means South Africa has exceeded its official prison national occupancy level by 31.7\% (World Prison Brief, 2013). Furthermore, this high occupancy level has resulted in an uneven warderprisoner ratio. At the last count, the warder-prisoner ratio in South Africa stood at 1:25 (Muntingh, 2009). This disproportionate prisoner-warder ratio, which is a result of increasing numbers of inmates without a corresponding growth in the number of wardens, is higher than accepted global prison security standards. It is also of concern in relation to prison functionality, staff security, occupational health and morale. In an effort to address these staffing deficiencies which impact the prisoner-warder ratio, the Department of Correctional Services has since July 2010 embarked on a vigorous recruitment drive to fill 6657 vacancies which account for $14 \%$ of the Department's approved staff establishment (DCS, 2011). By 2011, 1844 of these vacancies had been filled. However, these new correctional services personnel accounted for only $28 \%$ of the total vacancies (DCS, 2011) meaning the number of offenders continues to be disproportionate to the number of warders. This prisoner-warder ratio parity and cell occupancy levels (or density) are crucial in determining the safety of offenders and correctional services staff because high occupancy levels coupled with few correctional officers increase security risks in the correctional facility. A disproportionate prisoner-warder ratio also has negative implications on the practicality of implementing rehabilitation programmes in correctional facilities. This is because the few available warders cannot effectively balance their security duties and implementation of offender rehabilitation programmes.

The disproportionate prisoner-warder ratio is partly an indication of overcrowding in South African correctional facilities. The latest statistics show that South Africa's prison population of 156370 is higher than the official capacity of the country's prison system which can only accommodate 118968 (World Prison Brief, 2013). Due to this surpassing of the official carrying capacity, the national occupancy level (based on official capacity) is $131.7 \%$ (World Prison Brief, 2013) meaning South Africa's prisons are overcrowded. In addition to the density measurement (i.e., measure of physical floor space per prisoner), it must be remembered that there is also overcrowding perception which is a subjective measure. Whether an inmate perceives prison conditions as crowded depends on objective crowding conditions and on the relative differences in crowding within a prison's housing accommodations (Muntingh, 2009). This means there is always need to remember that overcrowding is not only about numbers, it has a strong qualitative aspect to it which allows deduction of its effects on prisoner rehabilitation, recidivism rates, employee wellness and relations (Muntingh, 2009). The negative effects of prison overcrowding on inmates are fairly well documented. A number of scholars agree that prisons housing significantly more inmates than a design capacity based on sixty square feet per inmate are likely to have high assault rates (Gaes, 1992; Fagan, 2002; Morgan et al., 2002). Other scholars however dispute this, arguing that there is no direct relationship between prison overcrowding and prison violence or other forms of misconduct. There is however consensus that overcrowding can itself induce stress for inmates. In other prison situations, overcrowding may act as an intensifier of stressful prison conditions that have been precipitated by other causes with consequences that can at worst be life threatening (Penal Reform International 2012; Gaes, 1985). Furthermore, Huey and McNulty (2005) argue that prison overcrowding has ethnographical consequences on prisoners' well-being. These ethnographical factors include deficient medical attention, diminished security, lack of access to rehabilitative programs, and relentless idleness. 
It has to be noted that many studies have predominantly looked at the negative effects of prison overcrowding on offenders while neglecting the effects of the same on correctional services personnel. This dearth of research focusing on prison personnel ignores the fact that in as much as prison overcrowding has ethnographical effects on prisoners, the same can be said for prison officials. There is emerging evidence which supports this line of argument. For example, Muntingh (2009) argues that prison understaffing and overcrowding has negative impacts on prison staff manifested by high staff turnover, excessive leave, high rates of sick leave and absenteeism. These factors have potential to prevent prisons from implementing and fulfilling their operational functions. Cheek and Miller (1983) further note that stress among correctional officers is partly caused by overcrowding. Stress induced by overcrowding compounds high stress levels which are a result of the risky occupation itself. This is corroborated by Lindquist and Whitehead (1986) who found that $68 \%$ of correctional officers considered their job to be at least moderately stressful whilst approximately $33 \%$ reported experiencing symptoms of burnout. The foregoing argument is not meant to diminish the fact that stress among correctional officers is also partly caused by workload, lack of participation in decision making, contact with inmates, anticipation of contact with inmates, and confrontation with inmates (Cheek and Miller, 1983). Physical 'dangers' associated with potential harm by inmates are also a partial cause of stress among correctional officers. This is partly due to the correctional facility environment which is considered a 'tough', 'dangerous' place of employment dominated by machismo attitudes among offenders (Morgan et al., 2002). But is this the state of affairs in South African correctional facilities? This is one of the many questions that this article addresses through its examination of the prisoner-warder ratio parity and working environment at the East London Maximum Correctional Centre (ELMCC) case study.

\section{Methodology}

This study utilises a qualitative research approach. Such a research methodology - which is a systematic empirical inquiry into meaning - is ideal in the present study which seeks to capture the views, experiences and feelings of people (Babbie and Mouton, 2011) in relation to the effects of prison overcrowding on the correctional centre working environment and warder work motivation and morale. Furthermore, a qualitative approach allows the study to understand the research problem from participants' perspectives since their views, insights and concerns (Marvasti, 2004) are the foundation that informs the empirical analysis and analytical generalisations. Within the qualitative approach, in-depth semi-structured interviews, key informant interviews and focus group discussions were used as data collection instruments. This data was collected from the East London Correctional Centre (ELCC), which consists of three centres; Maximum Centre, Female Centre, and Juvenile Centre. This study focused on the Maximum Centre (herein called the East London Maximum Correctional Centre-ELMCC) which had a total of 1329 prisoners and 300 personnel who include direct security personnel and administrative personnel. Using purposive sampling (see Babbie and Mouton, 2011, Babbie, 2013) a total of 24 respondents were selected and interviewed. Since this is a qualitative study, such a sample size was ideal to generate rich in-depth quality data for empirical analysis allowing analytical generalisations and conclusions.

A total of 11 females were interviewed. Out of these 11 females, eight were between the ages of $35-44$ years and three were in the 45 - 54 years age group. Seven of these females were black Africans, two were coloured, one was Indian and the last one was white. From the 13 males interviewed, six were in the $35-44$ years age group while the remaining seven were in the 45 - 54 years age group. Out of these 13 male respondents, six were black Africans, four were coloured, one was Indian and the remaining two were white. The above socio-demographic statistics indicate that the centre has a high number of black African correctional officers aged between 35 and 44 years. This racial composition of personnel is somehow expected in a province (Eastern Cape) and country where the majority are predominantly black Africans. In terms of education, the highest qualification among the majority of respondents was Grade 12 with seven females and nine males educated up to that level. This low level of education among correctional officers is again not a surprise because a tertiary level certificate, diploma or degree is not a prerequisite for employment as a correctional officer in South Africa. While all the respondents had more than 10 years working experience in the DCS, most of the female respondents (73\%) had been correctional officers for between 15 and 24 years while $54 \%$ of the male respondents had served for the same period of time. 
Prisoner-personnel ratio parity at the East London Maximum Correctional Centre: Discussion of Findings: At the ELCC, the East London Maximum Correctional Centre (ELMCC) had the highest number of personnel (300), as well as the highest number of inmates (1329). Using these figures, the personnel-inmate ratio was thus 1:4. The ideal, standard international ratio (according to respondents) is 1:3 in a Maximum Centre. A cursory look gives the impression that not much disparity exists since the ratio is very close to the accepted international standards in a Maximum Centre. However, this statistic is misleading. One has to examine prisoner-personnel direct contact hours to clearly determine the correct ratio as elaborated below. In the ELMCC there are two working divisions, Division A and Division B. The 300 personnel mentioned above are distributed in both Divisions in five working shifts. The first shift works for 12 hours starting at 06:00am until 18:00pm. The second shift starts at 07:00am until 15:30pm, the third from 06:00am to $14: 00 \mathrm{pm}$, the fourth from $18: 00 \mathrm{pm}$ to $06: 00 \mathrm{am}$ and the last from 23:00pm to 06:30am. Division A and Division B work separate 12 hour shifts (either the $06: 00 \mathrm{am}$ to $18: 00 \mathrm{pm}$ or 18:00pm to $06: 00 \mathrm{am}$ shift), and both Divisions combine in the 8.5 hours shift $(07: 00 \mathrm{am}$ to $15: 30 \mathrm{pm})$ and the 7.5 hours shift $(23: 00 \mathrm{pm}$ to 06:30am). Only a selected few from both Divisions work the 8 hour shift from 06:00am to 14:00pm, and these are primarily from the administration, hospital and kitchen units. This therefore indicates that the 300 personnel in the ELMCC are not all on duty at the same time due to the shift patterns. They also do not leave work at the same time, again due to the shift patterns. This means that the above mentioned ratio of 1:4 (based on 300 personnel and 1329 inmates) is incorrect and thus does not apply in the ELMCC. Furthermore, not all 300 personnel in both Divisions (A and B) are warders working in direct contact with inmates. Some are non-security office personnel working in the human resources department while others work in the administration office, cash office, social work unit, psychology unit, school, kitchen and hospital (see table 1 below).

Table 1: ELMCC Personnel in Non-security Departments

\begin{tabular}{lll}
\hline Non Security Departments & Division A (no. of personnel) & Division B (no. of personnel) \\
\hline Human Resources & 6 & 6 \\
Administration Office & 5 & 5 \\
Cash Office & 2 & 1 \\
Psychology and social work unit & 5 & 5 \\
School & 12 & 12 \\
Kitchen & 3 & 4 \\
Hospital and Pharmacy & 5 & 4 \\
TOTAL & 38 & 37 \\
\hline
\end{tabular}

Source: Field data, 2011

The above non-security personnel therefore have to be subtracted from total personnel when calculating the prisoner-warder ratio. Furthermore, the remaining personnel total (after subtracting non-security personnel) still contains night shift staff, local hospital duty and escort staff (see table 2 below) which must also be subtracted from the total in order to determine the precise onsite prisoner-warder ratio.

Table 2: ELMCC Night Shift Staff, Local Hospital Duty and Escort Staff

\begin{tabular}{lll}
\hline & Division A & Division B \\
\hline Night shift & 20 & 18 \\
Frere hospital duty & 4 & 6 \\
Escort duty & 6 & 11 \\
TOTAL & 30 & 35 \\
\hline
\end{tabular}

Source: Field data, 2011

A precise onsite prisoner-warder ratio can thus only be arrived at after subtracting personnel in tables 1 and 2 from total staff. Using that formula, the study found that both Division A and B have a total of 77 personnel in direct security contact with inmates which translates to a prisoner-warder ratio of 1:9 at the ELMCC. This is above the recommended international standard ratio of 1:3. When the shift patterns stated earlier are used to further disaggregate this data based on approximately 25 warders per shift (as indicated by respondents), these results in a prisoner-warder ratio of 1:53 per shift onsite. Again, this is way above the recommended international standard ratio of 1:3. It is important to note that the ratio indicated here is an approximate ratio 
which only takes into consideration the number of prison personnel assumed to be on duty on any given day. In other words, the ratio does not take into account personnel who were absent due to annual or sick leave, a situation which may further increase the disproportionate prisoner-warder ratio. It is also important to emphasise that the prisoner-warder ratio calculated here is more accurate compared to the one normally used by the DCS. This is because the present determination only considers those personnel who have direct security contact with inmates as opposed to DCS's which includes every staff member in its calculation. It is also worth noting that the disproportionate prisoner-warder ratio at the ELMCC mirrors the situation in some South African maximum security prisons such as Vereeniging where Rawoot (2011) observed four warders in charge of 300 maximum security prisoners. This indicates that the disproportionate prisonerwarder ratio is not only limited to the ELMCC in South African prisons but appears to be prevalent across the Correctional Services system. Given the implications of this disproportion on prison security, it is obvious that this is an aspect of the South African Correctional Services system that requires urgent policy and practical intervention measures to align it with accepted international standards.

The disproportionate prisoner-warder ratio and shift patterns discussed here have a number of effects on direct security personnel on duty as well as inmates. The majority of interviewees (96\%) identified high absenteeism as one of the negative outcomes of the disproportionate prisoner-warder ratio. Absenteeism was rife with personnel frequently on sick leave while some were on temporary incapacity leave. Incapacity leave is leave taken by a staff member who has exhausted his/her leave days per annum. In addition, high stress levels were also reported by $96 \%$ of respondents. This resonates with earlier conclusions by Higgins and Tewkbury (2006) as well as Whiteacre (2006). These high stress levels at the ELMCC had pushed 88\% of the respondents into high alcohol consumption in an attempt to temporarily escape stress induced mental torture. As one respondent noted; "the prison is overcrowded. These conditions are posing a great risk to us. We feel that our lives are in danger. Our stress levels are high. That is why you find members stressed and drinking on duty". Another respondent added:

We are stressed, overworked, tired. To give you an example I work in unit 4, we have 320 inmates and there are 7 members on duty as we speak...Because of the shifts, 2 of those members are leaving at 13:30 which leaves us with 5. That means that 5 members are working with 320 inmates and from that 5 one is not a security officer but is a case management officer who has left his own work to help us feed and lock up.

Furthermore, the findings show that of the 19 (79\%) respondents who reported ill health as an effect of prison overcrowding, 12 (63\%) attributed this (ill health) directly to the stressful environment of their workplace, whist the remaining 7 (37\%) respondents attributed ill health to alcohol consumption (which is a consequence of the environmental factors found at their work place). Fear of inmates was also of major concern among the warders. A total of $16(66 \%)$ respondents reported perpetual fear in their workplace due to the risky insecure overcrowded work environment with very few direct security warders. The effect of prisoner-warder ratio disparity on work performance, cognitive job satisfaction and organizational commitment was also examined. A majority $96 \%$ of the respondents indicated that they perform poorly at work. This, according to one respondent (out of many similar responses), was due to the fact that there is "no daily planning of work and this leads to our work being disorienting. We cannot do our work on time at all...We constantly need to help out where there is a staff shortage especially during feeding times". Poor work performance was also related to low cognitive job satisfaction by the respondents. Using working hours, pay, promotional opportunities and work incentives to measure their cognitive job satisfaction (see Moorman, 1993, Latham and Budworth, 2007), 96\% of the respondents indicated that they have low job satisfaction. As one respondent explained:

We can't really say we have high job satisfaction. We run away from work in stand of running into work... We are not happy here. Before the new government, the environment was pleasant we could work and we loved our jobs but now we get no promotions, we pay for medical aid when we never used to, we are over worked and under paid.

Although some personnel had low cognitive job satisfaction, a majority (68\%) were found to have high organisational commitment. The $68 \%$ with high organisational commitment were found to be those with over 15 years of service, and mostly male. Although it sounds like a simplistic debatable generalisation and cliché, 
this finding resonates with observations by Fagan (2002) who notes that the majority of male staff (in his study) had a higher commitment to organizations than their female counterparts. He adds that while male staff predominantly perceived work from an 'organizational growth' perspective, some females were more interested in the incentives they receive from an organisation arguing these carried more weight for them.

\section{Conclusion}

From the foregoing arguments, it is clear that there is a disproportionate prison-warder ratio at the ELMCC. This disproportion is symptomatic of a wider institutional deficiency across the South African Correctional Services system. Viewed against the expected (and accepted) international prisoner-warder ratio standards, the South African system thus falls short on many accounts with dire consequences on the prison work environment and correctional security personnel. The high absenteeism by warders (be it on sick leave or temporary incapacity leave) as they seek to escape a stressful work environment characterised by staff shortages compromises security levels and standards at the ELMCC. This has direct negative implications on the rehabilitation efforts and activities of the correctional system. The fact that many warders have resorted to alcohol abuse in an attempt to deal with work related stress is an issue that calls for immediate intervention by the DCS. While educating warders about the health consequences of alcohol abuse and enrolling them in alcohol addiction rehabilitation programmes might be an immediate intervention by the DCS addressing a visible occupational health problem, what is needed in the long term is a sustainable solution to the staffing shortages. Staffing shortages are the root of many of the problems poisoning the ELMCC work environment hence addressing them will go a long in alleviating warder absenteeism, work related stress and alcohol abuse etc. It can equally be said that if staffing is improved, the work performance and organisational commitment of some warders might improve owing to reduced working hours. Reduced working hours also have potential to improve warder morale and motivation thereby partly contributing to an improvement in cognitive job satisfaction.

\section{References}

Babbie, E. (2013). The Practice of Social Research, Wadsworth: Cengage Learning.

Babbie, E. \& Mouton, J. (2011). The Practice of Social Research, Cape Town: Oxford University Press Southern Africa.

Cheek, F. \& Miller, M. (1983). The experience of stress for correctional officers: A double-bind theory of correctional stress. Journal of Criminal Justice, 11, 105-130.

Citypress. (2013). Prison population at 156 000, more than a quarter awaiting trial [online]. Available at: http://www.citypress.co.za/news/prison-population-at-156-000-more-than-a-quarter-awaitingtrial/ [Accessed 23 May 2014]

Department of Correctional Services. (2008). Strategic Plan 2008/09 [online]. Available at: http://www.dcs.gov.za/Publications/Strategic\%20Plans/Strategic\%20Plan\%20200809\%20to\%202012-13.pdf [Accessed 16 June 2011].

Department of Correctional Services. (2009). Annual Report for 2008/09 Financial Year [online]. Available at: http://www.dcs.gov.za/Publications/Annual\%20Reports/DCS\%20Annual\%20Report\%202010.pdf [Accessed 16 May 2011].

Department of Correctional Services. (2009). Strategic Plan for 2009/10 [online] Available at: http://www.dcs.gov.za/Publications/Strategic\%20Plans/Strategic\%20Plan\%20200910\%20to\%202013-14.pdf [Accessed 16 May 2011]

Department of Correctional Services. (2011). Annual Performance Plan 2011/12 [online].Available at: http://www.dcs.gov.za/Publications/Annual\%20Reports/DCS\%20Annual\%20Perfofmance\%20Plan \%202011.pdf [Accessed 16 May 2011].

Evans, S. (2013). White paper promises changes for those awaiting trial [online]. Available at: http://mg.co.za/article/2013-09-06-00-white-paper-promises-changes-for-those-awaiting-trial [Accessed 20 May 2014].

Fagan, H. (2002). Prison overcrowding: One of our biggest challenges to transformation. Prison Transformation in South Africa, 11(2), 16-19.

Gaes, G. (1985). The effects of overcrowding in prisons. Crime and Justice, 6, 95-147. 
Higgins, G. E. \& Tewkbury, R. (2006). Prison staff and work stress: The role of organizational and emotional influences. American Journal of Criminal Justice, 30, 247-266.

Huey, M. P. \& McNulty, T. L. (2005). Institutional conditions and prison suicide: Conditional effects of deprivation and overcrowding. The Prison Journal, 85, 490-514.

IOL. (2008). SA prison population amongst the world's highest [online]. Available at: http://www.iol.co.za/news/south-africa/sa-prison-population-among-world-s-highest-1.398070 [Accessed 26 March 2011]

Latham, G. P. \& Budworth, M. H. (2007). The study of work motivation in the 20th century, in L. L. Koppes (ed.) Historical perspectives in industrial and organizational psychology, Mahwah, NJ: Lawrence Erlbaum.

Lindquist, C. \& Whitehead, J. (1986). Burnout, job stress and job satisfaction among Southern correctional officers: Perspective and causal factors. Journal of Offenders Counselling, Service and Rehabilitation, 10, 5-26.

Marvasti, A. B. (2004). Qualitative Research in Sociology: An Introduction, London: Sage.

Moorman, R. H. (1993). The influence of cognitive and affective based job satisfaction measures on the relationship between satisfaction and organizational citizenship behaviour. Human Relations, 6, 759776.

Morgan, D. R., Van Haveren, A. R. \& Pearson, A. C. (2002). Correctional officer burnout: Criminal Justice and Behaviour. American Association for Correctional Psychology, 29(2), 144-160.

Muntingh, L. M. (2009) Surveying the prisons landscape: What the numbers tell us. Law, Democracy and Development, 9(1), 21-44.

Penal Reform International. (2012). Ten-point plan to reduce prison overcrowding [online]. Available at: http://www.penalreformorg [Accessed 23 May 2014].

Rawoot, I. (2011). St Albans prison: No escape from hell behind bars [online]. Available at: http://mg.co.za/article/2011-01-21-no-escape-from-hell-behind-bars [Accessed 28 May 2014].

Whiteacre, K. W. (2006). Measuring job satisfaction and stress at a community corrections center: An evidence-based study. Corrections Today, 68, 70-73.

World Prison Brief. (2013). Africa, International Centre for Prison Studies [online]. Available at: http://www.prisonstudies.org/info/worldbrief/?search=africa\&x=Africa [Accessed 29 October 2013]. 